\title{
Strengthening the evidence base on social accountability for improving family planning and reproductive health programs
}

Victoria Boydell

Jill Keesbury

Kelsey Wright

Follow this and additional works at: https://knowledgecommons.popcouncil.org/departments_sbsr-rh

Part of the Civic and Community Engagement Commons, Demography, Population, and Ecology Commons, Family, Life Course, and Society Commons, International Public Health Commons, and the Women's Health Commons

How does access to this work benefit you? Let us know!

\section{Recommended Citation}

Boydell, Victoria, Jill Keesbury, and Kelsey Wright. 2014. "Strengthening the evidence base on social accountability for improving family planning and reproductive health programs," Meeting report. Washington, DC: Population Council, Evidence Project. 


\section{Strengthening the Evidence Base}

on Social Accountability for Improving Family Planning and Reproductive Health Programs

Experts Meeting London, England July 16-17, 2014 


\section{The Evidence Project}

Population Council

4301 Connecticut Avenue, NW, Suite 280

Washington, DC 20008 USA

Tel : +1202 2379400

Email : evidenceproject@popcouncil.org

evidenceproject.popcouncil.org

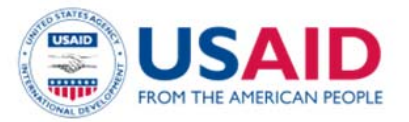

The Evidence Project is made possible by the generous support of the American people through the United States Agency for International Development (USAID) under the terms of cooperative agreement no. AID-OAA-A-13-00087. The contents of this document are the sole responsibility of the Evidence Project and Population Council and do not necessarily reflect the views of USAID or the United States Government.

\section{Evidence}

The Evidence Project uses implementation science-the strategic generation, translation, and use of evidence — to strengthen and scale up

family planning and reproductive health programs to reduce unintended pregnancies worldwide. The Evidence Project is led by the Population Council in partnership with INDEPTH Network, International Planned Parenthood Federation, Management Sciences for Health, PATH, Population Reference Bureau, and the project's University Resource Network.

Published in October 2014

Suggested Citation: Boydell, Victoria, Jill Keesbury, and Kelsey Wright. 2014. "Strengthening the Evidence Base on Social Accountability for Improving Family Planning and Reproductive Health Programs," Meeting Report. Washington, DC: Population Council, Evidence Project.

(C) 2014 The Population Council, Inc. 



\section{Table of Contents}

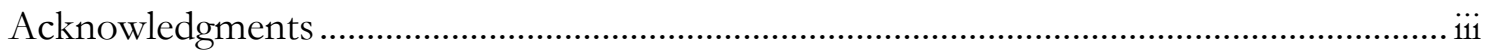

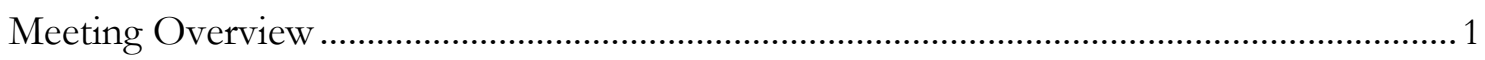

Setting the Stage: Reviewing the Evidence on Social Accountability.................................. 3

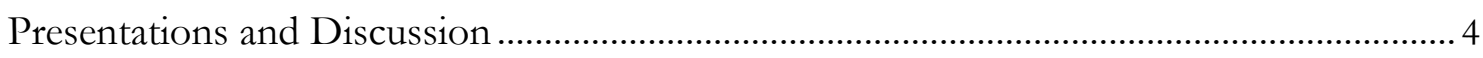

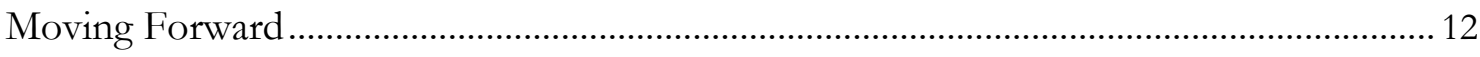

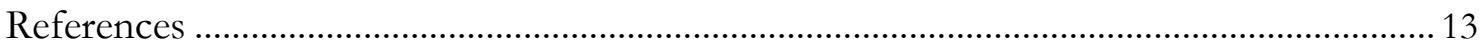

Appendix 1: Experts Meeting Agenda ….......................................................................... 14

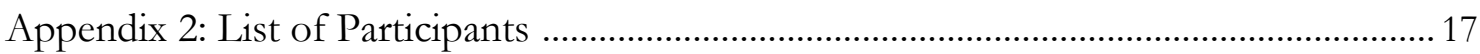




\section{Acknowledgments}

This experts meeting was funded by the United States Agency for International Development (USAID) through the Evidence Project. The organizing committee included: Jill Keesbury from the Evidence Project/PATH, Victoria Boydell from the Evidence Project/International Planned Parenthood Federation (IPPF), Erin McGinn from the Health Policy Project, Caroline Poirrier from Results for Development, and Sarah Shaw from IPPF. Karen Newman served as meeting facilitator.

We would like to thank Mihira Karra and Erika Martin of USAID for their support of this meeting. We also thank the speakers: Marta Schaaf, Senior Program Officer, Averting Maternal Death and Disability Program, Mailman School of Public Health, Columbia University; Anuradha Joshi, Team Leader, Institute of Development Studies, University of Sussex; Esperenza Delegado, Director of International Relations, Mexican Foundation for Family Planning (Mexfam); Poonam Muttreja, Executive Director, Population Foundation of India; Nina Miller, Manager for the Performance Monitoring \& Accountability Working Group, FP2020; Pasiens Mapunda, Deputy Country Representative, Pathfinder International Tanzania; Duff G. Gillespie, Professor, Johns Hopkins Bloomberg School of Public Health; John Townsend, Vice President, Reproductive Health, Population Council; Susanna Dennis, Senior Research Associate, Population Action International; and Laura Malajovich, Regional Advocacy Officer, IPPF Western Hemisphere Region.

This report was prepared by Victoria Boydell, Jill Keesbury, and Kelsey Wright of the Evidence Project. Thanks to Karen Hardee, Ellen Weiss, and Rob Pursley for technical and editorial support. 



\section{Meeting Overview}

Over the last decade, the concept of accountability has received increased attention among development practitioners, particularly regarding aid effectiveness. At its most basic, accountability entails "the duty to provide an account (by no means necessarily a financial account) or reckoning of those actions for which one is held responsible. This accountability involves two responsibilities or duties: the responsibility to undertake certain actions (or forebear from taking these actions), and the responsibility to account for those actions" (Cronin and O'Regan 2002, p. viii).

The concept of accountability is important in the family planning (FP) and reproductive health $(\mathrm{RH})$ sector as well, building on a rich history of community involvement and civil society participation. There are three distinct categories of FP/RH accountability initiatives operating at different levels: tracking donor and government financial commitments, tracking national-level program implementation, and tracking service delivery outcomes, as shown in Table 1.

The third category, often referred to as social accountability, includes the efforts of citizens and civil society to scrutinize and hold duty bearers (politicians, government officials, and service providers) to account for providing promised services, most often at the sub-national or community levels. Social accountability is premised on the assumption that increased and targeted citizen and civil society engagement and action will force public officials to act on their commitments.

Table 1. Categories of FP/RH Accountability Activities

\begin{tabular}{|c|c|}
\hline $\begin{array}{l}\text { Categories of FP/RH } \\
\text { Accountability Activities }\end{array}$ & Illustrative Initiatives \\
\hline $\begin{array}{l}\text { Tracking donor and government } \\
\text { financial commitments }\end{array}$ & $\begin{array}{l}\text { - } \quad \text { FP2020 } \\
\text { - The Netherlands Inter-Disciplinary Demographic Institute's } \\
\text { Resource Flows } \\
\text { - The World Health Organization's National Health Accounts } \\
\text { and System of Health Accounts } \\
\text { - DSW - Euroleverage Project } \\
\text { - Population Action International - Budget Tracking Advocacy }\end{array}$ \\
\hline $\begin{array}{l}\text { Tracking national program } \\
\text { implementation }\end{array}$ & $\begin{array}{l}\text { - } \quad \text { The Gates Institute's PMA2020 } \\
\text { - } \quad \text { Advance Family Planning (AFP) } \\
\text { - The Deliver Project } \\
\text { - } \quad \text { Countdown to } 2015\end{array}$ \\
\hline Tracking service delivery outcomes & $\begin{array}{l}\text { - Pathfinder - Community Scorecard and Report Card in } \\
\text { Tanzania } \\
\text { - CARE - Community Scorecard in Malawi } \\
\text { - International Planned Parenthood Federation/Western } \\
\text { Hemisphere Region- Social Audits in Dominican Republic } \\
\text { and Panama } \\
\text { - White Ribbon Alliance - "Social Watch" in various countries }\end{array}$ \\
\hline
\end{tabular}

Social health policy is focusing increasingly on social accountability to improve quality of services and increase their uptake (Brinkerhoff 2004; George 2003; Murthy and Klugman 2004). Social accountability interventions have the potential for addressing misuse of public funds, staff vacancies, poor infrastructure, and ensuring that resource allocations meet legal requirements, professional standards, and societal values (Brinkerhoff 2004). While social accountability efforts are conceptually 
linked by a set of assumptions (i.e. more information about service quality and access leads to citizen action, which will command the state to respond), specific interventions differ significantly in form and scope. These range from participatory mechanisms such as participatory budgeting to those with watchdog functions like report cards.

Despite growing interest, significant gaps remain in the evidence of social accountability's effectiveness in general, and specifically for FP/RH. Many questions remain about how to best employ social accountability interventions within the FP/RH sector and their usefulness and effectiveness in affecting desired change. Does the implementation of accountability interventions in $\mathrm{FP} / \mathrm{RH}$ programs improve client access to, and quality of, services? What is the evidence for the effectiveness of social accountability interventions' improvement of client access and quality of services? Which specific accountability interventions are most effective in expanding access to highquality $\mathrm{FP} / \mathrm{RH}$ programming?

To help answer these and other questions, the Evidence Project convened an expert consultation, "Strengthening the Evidence Base on Social Accountability for Improving Family Planning and Reproductive Health Programs" on July 16-17, 2014 hosted by the International Planned Parenthood Federation, an Evidence Project partner, at their Central Office in London (see Appendix 1 for the meeting agenda).

The overall aim of the meeting was to develop an understanding of social accountability for improving FP/RH programs and to identify gaps in the evidence base that can be addressed by the Evidence Project.

The meeting's specific objectives were to:

- Discuss the applicability of findings from social accountability in other sectors to FP/RH programs, and

- Identify promising FP/RH social accountability interventions and appropriate measurement strategies to assess effectiveness.

More than 30 people attended the consultation, including implementers, technical experts, and scholars with general expertise on social accountability interventions from a range of fields such as maternal health, governance, and education, as well as FP/RH program experts with interest or experience in social accountability interventions. This diversity of participants allowed for a rich, cross-sectoral discussion that demonstrated how interdisciplinary learnings from a variety of settings can be applied the FP/RH field. A full list of attendees is included in Appendix 2. 


\section{Setting the Stage: Reviewing the Evidence on Social Accountability}

To set the stage for this consultation, Victoria Boydell, Rights and Accountability Advisor for the Evidence Project, presented findings from Evidence's analysis of the social accountability literature in a variety of sectors including the health sector, focusing on review papers as well as individual case studies related to FP/RH programs. The presentation highlighted the debates and emerging lessons from the social accountability field for better understanding its potential for improving FP/RH programs. Key findings from the literature ${ }^{1}$ are:

- Nine types of social accountability tools are identified in the general literature, four of which have most frequently been applied within FP/RH: public expenditure tracking, citizen report cards, community scorecards, and information sharing or campaigns.

- In addition to identifying tools, the literature has begun to identify a set of central conditions for implementing effective social accountability interventions, including: a clearly articulated theory of change specifying the exact steps for incremental changes contributing to larger goals; linking community-driven accountability activities with official and formal redress and remedy mechanisms with real sanctions and incentives; and recognition that context matters, whether policy or micro-political relationships in a community.

- Despite promising examples, most existing evidence about social accountability interventions' effectiveness and impact is weak. Several reviews suggest that donors' expectations for accountability interventions' impact well surpass existing evidence about their actual impact and effectiveness.

- While much discussion in the FP/RH field focuses on developing global or national policy mechanisms for accountability, less emphasis is placed on exploring the relevance of 'social accountability' interventions for ensuring FP/RH service access and quality.

\footnotetext{
${ }^{1}$ For more information, please see: Boydell, Victoria. and Jill Keesbury. 2014. "Social Accountability: What are the Lessons for Improving Family Planning and Reproductive Health Programs? A Review of the Literature," Working Paper. Washington, DC: Population Council, Evidence Project. www.evidenceproject.popcouncil.org
} 


\section{Presentations and Discussion}

Meeting participants noted that this was a crucial time to explore the relevance of social accountability for FP/RH programs. As FP2020 works to take FP/RH services to scale in 69 countries it is critical that the resulting programs protect, respond, and expand people's choices. Participants agreed that social accountability offers an important mechanism for client involvement in determining, guiding, and monitoring these programs, and their inclusion in FP/RH programming warrants serious consideration. The challenge is to identify which overarching social accountability principles and approaches can be applied to FP/RH programming's specific needs.

The outcomes of the meeting discussions are organized in three sections: I) Key considerations for integrating social accountability within FP/RH programs; II) Priority research questions on social accountability and FP/RH; and III) Actions for furthering the integration of social accountability into $\mathrm{FP} / \mathrm{RH}$ programs.

\section{KEY CONSIDERATIONS FOR INTEGRATING SOCIAL ACCOUNTABILITY INTO FP/RH PROGRAMS}

Most of the meeting's discussions addressed developing a better understanding of social accountability interventions' benefits and constraints generally, and their specific applicability to FP/RH programs. Participants noted that many of the general principles and practices of social accountability interventions are applicable to $\mathrm{FP} / \mathrm{RH}$ programming, but with special considerations for translating those findings to the practice of ensuring access to quality FP/RH services. Those considerations with a consensus of importance among meeting participants are described in the following sections.

\section{Social accountability interventions have different strengths and limitations for improving $\mathrm{FP} / \mathrm{RH}$ outcomes.}

Discussions led to agreement that social accountability interventions may be best suited to address specific types of problems, such as improving service access and quality, reducing intransigent service errors, and improving systems supporting quality service provision. Participants felt that robustly defining the most appropriate problems for applying social accountability interventions would be valuable. Experience suggests that budget tracking tools and processes are good for finding blockages but need to be complemented by other actions to release funds; report cards are good at assessing quality of care and illicit fee and stock out prevalence but not for engaging citizens in dialogue. Specific social accountability tools likely have different strengths and weaknesses in improving FP/RH outcomes.

Participants also discussed where accountability interventions could be most useful for improving FP/RH programs. Social accountability interventions are thought to be particularly good at addressing national policy and resource issues and service quality issues in communities. Social accountability is generally good at diagnosing problems and can help determine actual system mechanics, but diagnostics need to be linked with social pressure, public hearings, monitoring, media, and political advocacy with politicians and line ministries for change to occur. 


\section{Social accountability interventions are more than just applying tools, they are complex political processes.}

One common understanding of social accountability is that it is a process of applying tools within an intervention for strengthening citizen engagement and improving program outcomes. Tools range from national budget tracking mechanisms to community-driven scorecards. Participants strongly agreed these tools should be components of an intervention and not interventions themselves. An exclusive focus on social accountability technical tools does not account for the political nature of social accountability, which aims to challenge and change power dynamics.

A social accountability intervention should be a set of interconnected, highly political activities that may use an individual tool, or set of tools, for a desired outcome. There was agreement that a focus on merely applying tools will not automatically create fundamental social change. A longer-term strategic and process-oriented approach is required (see Fox 2014).

The presentation by Esperanza Delegado, Advocacy Director for Mexfam, described a budget advocacy intervention by Mexfam in Mexico. Ms. Delgado emphasized that the accountability tool used, budget tracking, is part of a broader strategy that includes advocacy and lobbying. The tool itself is part of a successful social accountability intervention with additional efforts and advocacy required to achieve desired outcomes. In addition, Mexfam's efforts were not a singular intervention but part of longer process that started with securing a national budget line for commodities followed by working to ensure the budget line's financing, and finally the decentralization of funds to the states. The commonalities and overlap between social accountability and advocacy activities were repeatedly noted as part of the discussions around Delgado's presentation.

Marta Schaaf, Deputy Director, Averting Maternal Death and Disability, Columbia University, presented on the role of social accountability in FP/RH programs, clearly showing how focusing primarily on tools and their effectiveness can transform social accountability into a technical issue that fails to recognize the important social and political dimensions involved in bringing about change. A focus on specific tools and their applications leads to a process of de-politicization and separation of social accountability interventions from political realities. She noted that public officials are politicians with specific incentives and motivations that can actively determine a social accountability effort's success or failure. Based on her program experience, she argued for better understanding of the roles of informal and formal political processes, including the culture of systemic corruption, to understand the full context in which social accountability FP/RH interventions are implemented. The field of political science could offer methodological guidance to help social accountability interventions be more politically literate.

Meeting participants agreed that social accountability should be part of long-term and ongoing political engagement between social actors and the state with a range of specific outcomes. It was agreed that social accountability is not a panacea but can have significant effects for certain types of outcomes, which will need to be defined for each intervention. Instead of approaching interventions primarily with tools to be used, developing a theory of change to guide selection of intervention tools and approaches is more useful.

\section{Social accountability models must be adapted to reflect the realities of $\mathrm{FP} / \mathrm{RH}$ issues.}

Family planning and reproductive health programs are intended to affect two of the most complex and intimate aspects of people's lives: sex and reproduction. These intimate areas often have significant influence on people's personal and public roles and relationships, as well as the unspoken 
norms structuring their lives. As a result, FP/RH programs are often very different from other sectors where social accountability interventions are most commonly implemented, such as education and governance, along with health system services that prevent or cure diseases or illnesses, because $\mathrm{FP} / \mathrm{RH}$ programs are inherently politicized. It was agreed that FP/RH social accountability interventions cannot simply be "cut and pasted" from other sectors, but need to be carefully adapted to the realities of $\mathrm{FP} / \mathrm{RH}$ programming.

Christine Galavotti, Director of Sexual, Reproductive and Maternal health for CARE, emphasized these considerations in her presentation on the basic principles of a rights-based approach to $\mathrm{FP} / \mathrm{RH}$ services, providing an important foundation for non-FP/RH experts in attendance on the sector's unique characteristics. She detailed the implications of an initial perspective that family planning is a fundamental individual right for reproductive self-determination, allowing individuals to freely choose whether, when, and how many children to have. Rights-based FP/RH programs need to facilitate and, however possible, ensure full, free, and informed contraceptive choice through patientcentered and evidence-based care by supporting individual choice and ensuring privacy and confidentiality. Social accountability may serve as an important mechanism for operationalizing a rights-based approach for FP/RH services. Social accountability positions local communities as the watchdogs and judges of $\mathrm{FP} / \mathrm{RH}$ service accessibility and quality and offers communities a set of tools and processes for demanding improvements to the services to which they are entitled.

Discussion revealed the implications of the intimate nature of FP/RH for social accountability interventions:

- Tensions exist between the personal nature of FP/RH services and the public nature of many social accountability interventions: The interest in maintaining privacy and confidentiality for RH/FP services can conflict with the inherently public nature of social accountability. FP/RH decisions are very personal, and many women and their partners may not feel comfortable discussing those choices or their service experiences in public. Moreover, social accountability interventions require people to reveal their beliefs and practices publicly. FP/RH social accountability interventions must be aware of, and reflect, these concerns from the outset, and limited program experiences provide examples in handling these tensions.

- $\quad \boldsymbol{F P} / \boldsymbol{R H}$ programs may not enjoy widespread community support: Most examples of successful social accountability interventions are from sectors in which communities express widespread support for the targeted activity—such as decreasing maternal mortality or improving education. In many communities, $\mathrm{FP} / \mathrm{RH}$ programs remain controversial or are low priority due to their status as a women's issue and may not enjoy widespread support among community leaders. Mobilizing support for FP/RH social accountability interventions may pose a particular challenge, and social accountability may only be possible with larger community awareness and norms change efforts.

- Balancing the role of incentives in social accountability with choice and voluntarism: Given the potential for coercion, misuse, and abuse in FP/RH programs, safeguarding and promoting choice and voluntarism within social accountability work is important. Incentives are a key element in many social accountability interventions in other sectors because they provide important motivations for service providers and decisionmakers to respond to requests for improvement and change. The FP/RH sector has a long history, however, of negative consequences associated with incentives, which are seen as undermining the principles of voluntarism and choice. More consideration is needed for understanding whether social accountability incentives can be successfully applied in the 
$\mathrm{FP} / \mathrm{RH}$ sector, or if social accountability interventions can achieve desired results without incentives.

- Ensuring Inclusion: Participants agreed that social accountability has not historically been strong on issues of inclusion and equity for marginalized populations, which is an important issue for the FP/RH sector because those in need of public FP/RH services are often marginalized due to age, marital status, ethnicity, residence, income, religion, or gender. Because of their marginalization, these individuals are also often the least likely to actively participate in social accountability processes. Social accountability FP/RH interventions need to be able to incorporate equity and inclusion into their frameworks.

- Role of the private sector: Increasingly, FP/RH services are not only accessed through the public sector; NGOs, social marketing groups, pharmacies, and private clinics are taking on a larger role in these services. Social accountability interventions, however, have focused primarily on compelling "duty bearers" from the public sector to provide the services for which they are responsible. As the range of FP/RH providers expands, a key question is whether social accountability interventions can be used to hold private sector providers accountable for their quality of services.

- Achieving global standards and norms of care. There was discussion about the perceived gap between accountability interventions at the global level and local level efforts to improve quality of care. Nina Miller, Manager for the Performance Monitoring \& Accountability Working Group, FP2020, explained the different tools and platforms currently developed under FP2020 that could support the linkages between accountability at the global level and social accountability at a more local level. Meeting participants agreed that there is a lag between global accountability interventions and frontline social accountability interventions aimed at improving quality of care and performance.

- Measures are complex: Unlike certain sectors where rights-based issues are easily measured, such as water or primary education, the outcomes of reproductive choice and voluntarism are not easily quantified. Measures for increasing contraceptive prevalence are not sufficient to adequately reflect choices made by informed clients who may choose not to use a contraceptive method or by women who have limited options for contraception due to a limited method mix. Therefore, it is necessary to further explore indicators that reflect these particularities.

Overall, the group concluded that social accountability interventions hold great promise for improving FP/RH services, but that there are characteristics specific to $\mathrm{FP} / \mathrm{RH}$ programs that require adaption of social accountability models. Further research and field experience are needed to identify modes and methods for this adaptation.

\section{There is a need for more realistic expectations of the outcomes social accountability interventions can achieve within limited timeframes.}

Participants noted that social accountability interventions have the potential to achieve a wide range of outcomes. These outcomes will differ across the types of actors involved in the activity-state, society, and institutions. They can also differ in terms of the timeframe of the interventionimmediate changes can be improvements in specific services, while longer-term changes may include greater state-society interactions. Participants stressed that the effectiveness of social accountability interventions should be assessed in terms of realistic expectations of the different actors at different phases in the intervention. 
An important consideration is that $\mathrm{FP} / \mathrm{RH}$ programs are often operating in dysfunctional systems, which can make it difficult to know where to start programming and measurement. Both may require a systems approach, as identified problems can be linked to both upstream and downstream bottlenecks within the public sector system. This means tackling issues at all levels of public policy implementation, from changes in laws and policy, to changes in budget allocations for commodities, staff training, registration of medicines etc., to changes in the accessibility of quality services, such as ensuring regular staffing and convenient opening hours.

Participants agreed that it is critical for FP/RH social accountability interventions to clearly specify from the outset what the expected outcomes are. Programs aimed at creating more responsive service providers may prove quicker and easier to see results than those aimed at achieving changes in how the health system is managed. Shorter timeframes can show changes in service uptake, performance of providers, etc., but longer timeframes are required to assess changes in broader health and governance outcomes of social accountability FP/RH interventions. These longer time frames can be unfeasible from a funding or programmatic standpoint; however, the field needs to consider ways to rigorously demonstrate both short- and long-term change.

In his presentation, Pasiens Mapunda, Deputy Country Representative for Pathfinder International Tanzania, illustrated how projects' short timeframes are detrimental to achieving and demonstrating certain outcomes. For Pathfinder Tanzania, a one-year period to implement a report card to assess the provision of FP services at the community level limited the intervention's assessment to draw conclusive outcomes. Most of the project period was dedicated to stakeholder buy-in and collecting information for the first report card. There was not sufficient time to collect information about whether the intervention that revolved around the report card had made a difference in service delivery, let alone other types of outcomes such as changes to state-society relations and health outcomes.

Anu Joshi, from the Institute of Development Studies, University of Sussex, described how outcomes depend not just on timeframes, but also upon the context. Joshi's presentation suggested the need to move away from a linear approach of change consisting of gathering information that leads to citizen action that leads to state responses, toward a more dynamic representation of the people and processes involved in social accountability.

To understand and measure a range of social accountability FP/RH outcomes, it will be necessary to understand the context and placement of actors and actions within a more complex change framework. Additionally it will be necessary to unpack the underlying assumptions about how these changes will occur within systems. For example, when thinking about the role that citizen action plays in creating social change, it is necessary to consider citizens' awareness of the issue, the issue's importance to them, citizens' capacity for action, and the cost for collective action. Considering all of these issues will help determine milestones for setting and reaching long-term goals and for evaluating social accountability interventions.

\section{At a minimum, a social accountability intervention must ensure that citizens can access adequate information, that there is an effective citizen state interface, and that officials are willing and able to respond.}

There was much discussion on the specific conditions that are important for a social accountability intervention to work. Three conditions and accompanying questions emerged as being central to any social accountability intervention:

- Adequate data collection/information for citizens: Access to the information is an important part of accountability work but often health information systems are weak and it 
can be difficult to source the information for monitoring and tracking services or programs. This raises questions about how the lack of information or poor information determines what kind of social accountability questions can be asked and researched.

- Effective citizen-state interface: Both citizens and the state need to have the capacity and willingness to collaborate to identify issues and develop realistic and implementable solutions, and there are official spaces to dialogue with each other. But how can these capacities be built? How can this collaborative relationship be supported? How important is it to the success of an intervention to build on existing and credible forums for both citizens and state actors?

- Officials and service providers' are willing and able to respond: Information in the hands of citizens is not enough for accountability to work; it does not compel service providers and officials to act. Moreover, in a decentralized health system there are different points where accountability comes into play - at the policy level, and at the primary, secondary and tertiary service level. This affects officials' ability to respond because their decision-making roles will vary by level. How does change happen in this layered context? What are the most effective ways to ensure that the relevant authorities are willing, able, and resourced to respond? Is this even feasible in a context where there is little governance and law and order? How does this apply to services that fall outside the public health system?

The most important enabling factor to facilitate the above conditions is the space to bring together communities, service providers, and public officials to address identified problems and collaboratively develop solutions. Participants discussed the need to move beyond a dichotomy of citizen-state engagement toward collaborative actions. There was agreement that within current social accountability efforts there is a tendency to focus on civil society mobilization over supporting the state to respond and reinforce official accountability mechanisms.

Participants identified a range of internal conditions that need to be present before an organization undertakes a social accountability intervention. These include staff capacity (e.g. education level, degree of literacy, etc.) resources for training/mentoring, time available, a clear organizational commitment and strategy, and an ample budget.

\section{Important questions on scale and sustainability of social accountability interventions remain unanswered.}

There was much discussion about the long-term sustainability of accountability interventions, given that many of them are externally supported and require a high degree of investment or resources. Questions were also raised about what level of expansion constitutes "scale," whether contextspecific interventions could be replicated in other settings, and what skills, knowledge, and capacities are needed to take social accountability interventions to scale.

Poonam Muttreja, Executive Director of Population Foundation of India described the National Rural Health Mission's process of institutionalizing social accountability through community-based monitoring and planning (CBMP). The intervention started as a pilot in 36 districts in nine states and expanded nationally with support from state and national governments. The CBMP process resulted in positive changes to primary health centers, such as increased community input into health planning and reductions in clients' out-of-pocket expenditures. A key condition for scale-up was the close collaboration between the civil society organizations overseeing the CBMP process with the government, particularly the official government group supporting the work. Some key challenges were balancing the need to simplify the process with the need to ensure effectiveness, the capacity 
and willingness of local government to be active in the process, and the fact that many of the identified gaps in service delivery could not be addressed at the local level.

During the discussion, participants felt there was not enough information or experience of scale up to identify the facilitators and challenges to scale up of social accountability interventions and that work in this area is needed.

\section{QUESTIONS FOR FURTHER RESEARCH ON SOCIAL ACCOUNTABILITY FOR FP/RH}

The expert meeting sought to identify a set of priority research questions on social accountability for FP/RH programming. John Townsend, Population Council Vice President and Director of the Reproductive Health Program, identified two overarching questions that emerged during the meeting:

- What is the relevance of social accountability to FP/RH programming? Does it or does it not improve clients' access to $\mathrm{FP} / \mathrm{RH}$ services?

- What kind of outcomes can we expect to see in health, social development, and empowerment from integrating social accountability with FP/RH?

Participants also identified a set of more specific research questions that can be used to guide further inquiry. These issues were not prioritized during the discussion, suggesting an ambitious research agenda that requires collaboration among a range of actors in a variety of fields.

\section{How can FP/RH social accountability interventions be best applied and operationalized?}

- What specific problems in the FP/RH sector are best suited to social accountability interventions and tools?

- What are high impact practices? How can they be scaled up?

- What are the most critical changes that social accountability interventions can engender in diverse contexts, both from the supply and the demand sides, to improve FP/RH program outcomes?

- What are the key fundamental conditions for social accountability to be successful?

- How can social accountability be effectively applied to different health system levels and different parts of the health market (including the private sector)?

\section{What types of methodologies are necessary for capturing the varied impacts and outcomes of social accountability approaches?}

Much discussion was spurred by Caroline Poirrier, a Senior Program Officer with Results for Development, who presented a new study testing how a social accountability intervention can improve health services and outcomes. Ms. Poirrier described how the study combines a randomized control trial (on its effect is on quality of health service delivery and individual health practices) with qualitative research (on the mechanisms by which outcomes change, the role of context in shaping these effects, and whether interventions affect citizens' perceptions of empowerment and efficacy). 
Discussion focused on what types of evidence are needed. Are randomized control trials with ethnographies necessary to capture all elements of the change process? Do case studies focusing on process and implementing interventions exist? Are programs, or parts of programs, that didn't work being documented? Should studies compare FP/RH programs with and without social accountability activities?

\section{What can we learn from better documentation of existing programs?}

Meeting participants agreed there is a wide array of ongoing social accountability interventions that may not be labeled as such and may not have associated evaluations or research. They strongly agreed on the need for identifying existing social accountability interventions and integrating research and evidence generation within project cycles to produce rigorous findings about processes and outcomes.

These discussions led to the recognition that many FP/RH social accountability efforts and resources remain undocumented-and this lack of documentation prevents implementers and researchers from both employing, and contributing to important lessons. Randomized control trials are considered very rigorous and useful methodologically, but they are plausible only in specific contexts and not necessarily adept at identifying key causal factors in political processes, and these causal variables are part of an often complex and evolving political process that works in longer timeframes in the 'lumpy' reality of social relations.

The background paper consolidated available published literature, and the meeting produced a consensus about the need for better documenting the range of programs currently being implemented. Retrospective studies of interventions, rather than prospective ones, may be better suited for initially studying political processes that involve incremental changes among stakeholders. These studies could be complemented by extended observations and mini-ethnographies of ongoing actions to observe what is happening in situ. These lessons could be then be applied to current social accountability interventions for creating and bolstering rigorous research methods to evaluate and investigate social accountability interventions in the FP/RH field.

\section{Who is the research for?}

A recurrent question was "Who is the research on social accountability conducted for?" Is it for program implementers, to improve their programming? Is it for donors to monitor and assess their supported interventions? Is it for researchers to establish effectiveness or impact of such interventions? What are the information needs of these different audiences? How can we best collect this information without being burdensome? 


\section{Moving Forward}

The experts meeting began by recognizing, despite the emerging interest in social accountability, there is a limited understanding of what works and why. Throughout the meeting, the experts helped to better define what is unique about FP/RH - voluntarism, confidentiality, community empowerment - and reached consensus in recognizing a range of potential outcomes for social accountability FP/RH interventions, from improving service quality and health system performance to empowering civil society. To reach social accountability FP/RH interventions' full potentials, it is not possible to simply copy social accountability interventions in other sectors, rather it is necessary to start with sector-specific problems, identify desired outcomes, and then assess social accountability's relevance to them.

The meeting concluded with a call to surpass simply filling knowledge gaps on social accountability interventions' impact and effectiveness and, instead, generating a common agenda for future research that can be translated into concrete action for social accountability within FP/RH interventions. Suggested immediate activities include sharing information and documents, setting up a community of practice, and defining best or high-impact practices in the field. The Evidence Project is exploring the possibility of facilitating some of this information exchange.

Most immediately, the field would benefit from better documentation informed by the literature as well as leading experts. This is a role the Evidence Project can help advance - combining retrospective documentation with prospective studies of accountability interventions. By building on the findings and insights achieved from documenting ongoing or recently completed interventions, "good practices" in FP/RH social accountability can be identified, which can then be applied to strengthen ongoing FP/RH accountability interventions, which can be subsequently prospectively studied to determine their outcomes and impacts. 


\section{References}

Brinkerhoff, Derick W. 2004. "Accountability and health systems: toward conceptual clarity and policy relevance,” Health Policy and Planning 19(6): 371-379.

Cronin, Donal, and John O’Regan. 2002. “Accountability in Development Aid: Meeting Responsibilities, measuring Performance,” Research Report for Cómhlamh Aid Issues Group. Accessed on June 302014 from: http://www.dochas.ie/Shared/Files/4/Comhlamh_Research.pdf

Fox, Jonathan. 2014. 'Social accountability: What does the evidence really say?," Presentation prepared for the Global Partnership on Social Accountability.

George, Asha. 2003. "Using accountability to improve reproductive health care," Reproductive Health Matters 11(21):161-170.

Murthy, Ranjani K., and Barbara Klugman. 2004. "Service accountability and community participation in the context of health sector reforms in Asia: implications for sexual and reproductive health services," Health Policy and Planning 19(S1):i78-i86. 


\section{Appendix 1: Experts Meeting Agenda}

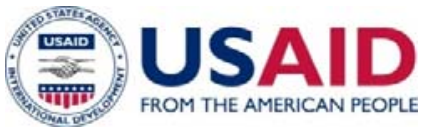

\section{Evidence}

Strengthening the Evidence Base on Social Accountability for Improving Family Planning and Reproductive Health (FP/RH) Programs

\section{An Experts Meeting}

International Planned Parenthood Federation • London, England• July 16-17, 2014

\section{MEETING OBJECTIVES:}

- Discuss the applicability of findings on social accountability in other sectors to social accountability for improving FP/RH programming

- Identify promising social accountability FP/RH interventions and appropriate measurement strategies to assess effectiveness

- Identify research priorities on social accountability in FP/RH programming

Wednesday, July 16

\begin{tabular}{|c|c|}
\hline Time & Session \\
\hline $9: 00-10: 30$ & $\begin{array}{l}\text { Introductions and Meeting Objectives } \\
\text { Welcome } \\
\text { - Owain James, Director of External Relations, IPPF } \\
\text { Participant Introductions } \\
\text { Meeting Introduction } \\
\text { - Jill Keesbury, Deputy Director, Knowledge Translation and Use, The Evidence } \\
\quad \text { Project/PATH }\end{array}$ \\
\hline $10: 30-10: 45$ & COFFEE \\
\hline $10: 45-11: 45$ & $\begin{array}{l}\text { What do we mean by "social accountability"? } \\
\text { Presentations } \\
\text { - "Social accountability: What does the literature tell us?" Victoria Boydell, The } \\
\text { Evidence Project/IPPF } \\
\text { - "The role of social accountability in FP/RH programs," Marta Schaaf, Senior } \\
\text { Program Officer, Averting Maternal Death and Disability Program, Mailman } \\
\text { School of Public Health, Columbia University } \\
\text { Discussion }\end{array}$ \\
\hline $11: 45-13: 00$ & $\begin{array}{l}\text { For a social accountability intervention to be effective, what are the key } \\
\text { elements that must be present? } \\
\text { Group work to identify the key elements of five social accountability interventions: } \\
\text { - Report card - Pasiens Mapunda, Deputy Country Representative, Pathfinder } \\
\text { International Tanzania }\end{array}$ \\
\hline
\end{tabular}




\begin{tabular}{|c|c|}
\hline & $\begin{array}{l}\text { - Budget tracking - Esperanza Delgado, Director of International Relations, } \\
\text { Mexican Foundation for Family Planning (Mexfam) } \\
\text { - Health committee - Poonam Muttreja, Executive Director, Population } \\
\text { Foundation of India } \\
\text { - Scorecard - Sara Gullo, Technical Advisor, Sexual, Reproductive and Maternal } \\
\text { Health, CARE } \\
\text { - Social audit - Ray Mitchell, Director of Advocacy and Campaigns, White } \\
\text { Ribbon Alliance }\end{array}$ \\
\hline $13: 00-14: 00$ & LUNCH \\
\hline $14: 00-15: 15$ & $\begin{array}{l}\text { Key elements, continued } \\
\text { Report back } \\
\text { Discussion }\end{array}$ \\
\hline $15: 15-16: 30$ & $\begin{array}{l}\text { Can social accountability interventions have a common theory of change? } \\
\text { Presentation } \\
\text { - "A theory of change for social accountability," Anuradha Joshi, Institute of } \\
\text { Development Studies, University of Sussex } \\
\text { Discussion }\end{array}$ \\
\hline $16: 30-16: 45$ & Wrap Up \\
\hline $18: 00-19: 30$ & Reception \\
\hline
\end{tabular}

Thursday, July 17

\begin{tabular}{|c|c|}
\hline Time & Session \\
\hline $9: 00-9: 15$ & Summary of Day One \\
\hline $9: 15-10: 15$ & $\begin{array}{l}\text { What does it take to implement a FP/RH social accountability intervention? } \\
\text { Group work to identify promising tools and approaches in building/ mobilizing human and } \\
\text { financial resources for implementing social accountability interventions. } \\
\text { Facilitator: Erin McGinn, Senior Technical Advisor, Health Policy Project, Futures Group. } \\
\text { - Report cards- Angella Langat, Knowledge Management Advisor, IPPF/Africa } \\
\text { - Regional Office } \\
\text { - Budget tracking- Karen Hoehn, independent researcher } \\
\text { - Health committees- Lulu Ng'wanakilala, Executive Director, UMATI } \\
\text { Presentation } \\
\text { - 'What does it take to support budget tracking efforts in Mexico," Esperenza } \\
\text { Delegado, Director of International Relations, Mexican Foundation for Family } \\
\text { Planning (Mexfam) }\end{array}$ \\
\hline $10: 15-10: 30$ & COFFEE \\
\hline $10: 30-11: 30$ & $\begin{array}{l}\text { Implementing a FP/RH social accountability intervention, continued } \\
\text { Report back. } \\
\text { Discussion }\end{array}$ \\
\hline
\end{tabular}




\begin{tabular}{|c|c|}
\hline $11: 30-13: 00$ & $\begin{array}{l}\text { Scale and sustainability: How can we go beyond 'context matters'? } \\
\text { Presentations } \\
\text { - "Replicating promising practices: the experience of the T4D evaluation } \\
\text { program," Caroline Porrier, Senior Program Officer, Results for Development } \\
\text { - "Institutionalizing social accountability within National Rural Health Missions," } \\
\text { Poonam Muttreja, Executive Director, Population Foundation of India } \\
\text { Discussion }\end{array}$ \\
\hline $13: 00-14: 00$ & LUNCH \\
\hline $14: 00-15: 30$ & $\begin{array}{l}\text { How do we measure outcomes and impact as well as the strength of } \\
\text { implementation? } \\
\text { Presentations } \\
\text { - "Quantifying dimensions of rights and empowerment," Nina Miller, Manager } \\
\text { for the Performance Monitoring \& Accountability Working Group, FP2020 } \\
\text { - "Challenges in monitoring and evaluating a Citizens Report Card in Tanzania," } \\
\text { Pasiens Mapunda, Deputy Country Representative, Pathfinder International } \\
\text { Tanzania } \\
\text { - "The Advance Family Planning's M\&E Methodology," Duff G. Gillespie, } \\
\text { Professor at Johns Hopkins Bloomberg School of Public Health } \\
\text { Discussion }\end{array}$ \\
\hline $15: 30$ & COFFEE \\
\hline $15: 50-16: 50$ & $\begin{array}{l}\text { Expanding the evidence base: What research priorities should The Evidence } \\
\text { Project take forward to advance the field of social accountability in FP/RH } \\
\text { programming? } \\
\text { Presentation } \\
\text { - "A synthesis of research priorities identified during the two-day meeting," John } \\
\text { Townsend, Vice President, Reproductive Health, Population Council } \\
\text { Discussion }\end{array}$ \\
\hline $16: 50-17: 15$ & $\begin{array}{l}\text { Fostering Partnerships } \\
\text { Presentation } \\
\text { - "The Budget Advocacy Network: A Recently Launched Accountability } \\
\text { Initiative," } \\
\text { Susanna Dennis, Senior Research Associate, Population Action International } \\
\text { and Laura Malajovich, Regional Advocacy Officer, International Planned } \\
\text { Parenthood Federation, Western Hemisphere Region } \\
\text { Discussion }\end{array}$ \\
\hline $17: 15-17: 30$ & Final Wrap Up \\
\hline $17: 30-18: 30$ & Marketplace with Joining Voices Meeting Participants \\
\hline
\end{tabular}




\section{Appendix 2: List of Participants}

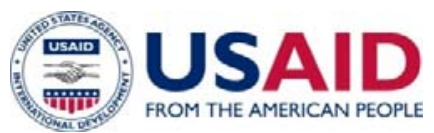

\section{Evidence}

Strengthening the Evidence Base on Social Accountability for Improving Family Planning and Reproductive Health (FP/RH) Programs

\section{An Experts Meeting}

International Planned Parenthood Federation • London, England • July 16-17, 2014

LIST OF PARTICIPANTS

\begin{tabular}{|c|c|c|c|}
\hline Name & Country & Institution & Title \\
\hline Angella Langat & Kenya & IPPF Africa Regional Office & $\begin{array}{l}\text { Knowledge Management } \\
\text { Advisor }\end{array}$ \\
\hline Anuradha Joshi & United Kingdom & $\begin{array}{l}\text { Institute of Development } \\
\text { Studies, University of Sussex }\end{array}$ & Team Leader \\
\hline Beth Scott & United Kingdom & $\begin{array}{l}\text { UK Department for } \\
\text { International Development }\end{array}$ & Health Advisor \\
\hline Caroline Poirrier & United States & Results for Development & Senior Program Officer \\
\hline Christine Galvotti & United States & CARE & $\begin{array}{l}\text { Director, Sexual, Reproductive } \\
\text { and Maternal Health }\end{array}$ \\
\hline Duff G. Gillespie & United States & $\begin{array}{l}\text { Johns Hopkins Bloomberg } \\
\text { School of Public Health }\end{array}$ & Professor \\
\hline Erika Martin & United States & $\begin{array}{l}\text { Research, Technology and } \\
\text { Utilization Division, Office of } \\
\text { Population and Reproductive } \\
\text { Health, USAID }\end{array}$ & Scale Up Advisor \\
\hline Erin McGinn & United States & $\begin{array}{l}\text { Health Policy Project, Futures } \\
\text { Group }\end{array}$ & Senior Technical Advisor \\
\hline \begin{tabular}{|l|} 
Esperenza \\
Delegado
\end{tabular} & Mexico & $\begin{array}{l}\text { Fundación Mexicana para la } \\
\text { Planeación Familiar (Mexfam) }\end{array}$ & $\begin{array}{l}\text { Director of Inter-institutional } \\
\text { Relations }\end{array}$ \\
\hline Jill Keesbury & United States & Evidence Project/PATH & $\begin{array}{l}\text { Deputy Director, Knowledge } \\
\text { Translation and Use }\end{array}$ \\
\hline
\end{tabular}




\begin{tabular}{|c|c|c|c|}
\hline Name & Country & Institution & Title \\
\hline John Townsend & United States & Population Council & $\begin{array}{l}\text { Vice President and Director of } \\
\text { the Reproductive Health } \\
\text { Program }\end{array}$ \\
\hline Jonathan Fox & United States & $\begin{array}{l}\text { School of International Service, } \\
\text { American University }\end{array}$ & Professor \\
\hline Karen Hoehn & Belgium & & Independent researcher \\
\hline Karen Newman & United Kingdom & Orry & Facilitator \\
\hline Katie Lau & United Kingdom & IPPF & Project Assistant ICPD \\
\hline Laura Malajovich & United States & $\begin{array}{l}\text { IPPF Western Hemisphere } \\
\text { Region }\end{array}$ & Regional Advocacy Officer \\
\hline Lulu Ng'wanakilala & Tanzania & UMATI & Executive Director \\
\hline Marta Schaaf & United States & $\begin{array}{l}\text { Mailman School of Public } \\
\text { Health, Columbia University }\end{array}$ & $\begin{array}{l}\text { Senior Program Officer, Averting } \\
\text { Maternal Death and Disability } \\
\text { Program (AMDD) }\end{array}$ \\
\hline Nina Miller & United States & FP2020 & $\begin{array}{l}\text { Manager for the Performance } \\
\text { Monitoring \& Accountability } \\
\text { Working Group }\end{array}$ \\
\hline Naomi Rutenberg & United States & Population Council & $\begin{array}{l}\text { Vice President and Director, HIV } \\
\text { and AIDS Program }\end{array}$ \\
\hline Pasiens Mapunda & Tanzania & $\begin{array}{l}\text { Pathfinder International } \\
\text { Tanzania }\end{array}$ & Deputy Country Representative \\
\hline Petrus Steyn & Switzerland & World Health Organization & $\begin{array}{l}\text { Human Reproduction, Family, } \\
\text { Women and Children's Health } \\
\text { Cluster, Department of } \\
\text { Reproductive Health and } \\
\text { Research }\end{array}$ \\
\hline Poonam Muttreja & India & Population Foundation of India & Executive Director \\
\hline Ray Mitchell & United Kingdom & White Ribbon Alliance & $\begin{array}{l}\text { Director of Advocacy and } \\
\text { Campaigns }\end{array}$ \\
\hline Ryan Figueiredo & India & IPPF South Asia Regional Office & Programme Specialist \\
\hline Sandra Jordan & United States & USAID & $\begin{array}{l}\text { Communications and Outreach } \\
\text { Advisor, Office of Population and } \\
\text { Reproductive Health }\end{array}$ \\
\hline Sara Gullo & United States & CARE & $\begin{array}{l}\text { Technical Advisor, Sexual, } \\
\text { Reproductive and Maternal } \\
\text { Health }\end{array}$ \\
\hline
\end{tabular}




\begin{tabular}{|l|l|l|l|}
\hline Name & Country & Institution & Title \\
\hline Sarah Shaw & United Kingdom & IPPF & Project Manager ICPD \\
\hline Susanna Dennis & United States & Population Action International & Senior Research Associate \\
\hline $\begin{array}{l}\text { Vanessa } \\
\text { Herringshaw }\end{array}$ & United Kingdom & Open Society Foundation & $\begin{array}{l}\text { Program Director, Transparency } \\
\text { and Accountability Initiative }\end{array}$ \\
\hline Victoria Boydell & United Kingdom & Evidence Project/IPPF & $\begin{array}{l}\text { Rights and Accountability } \\
\text { Advisor }\end{array}$ \\
\hline
\end{tabular}

